\title{
MAPS, FIGURES, AND TABLES
}

\section{Maps}

$\begin{array}{ll}\text { I. Algeria } & 17\end{array}$

2. Jewish Quarter of Oran 18

\section{Figures}

I.I. Jews in Ghardaia 13

I.2. Rue d'Austerlitz in the Jewish Quarter of Oran 18

3.I. Interior of the main synagogue of Oran 94

\section{Tables}

3.I. The Midrashim of Oran, I855

3.2. Health Conditions of Jewish Children in Oran's Midrashim, I855 
